\title{
Advantages of endophyte infection for irrigated pastures of semiarid, cold-desert environments
}

\author{
B.L. WALDRON \\ USDA-ARS, Forage and Range Research Laboratory, Logan, Utah, USA
}

blair.waldron@usu.edu

\begin{abstract}
Little research has evaluated possible endophyte benefits to adaptation and production of grasses in the irrigated pastures of the semiarid, cold-desert environments of the western USA. Severe irrigation shortages are common; however, production demands are increasing, necessitating maximizing tall fescue's (Festuca arundinacea Schreb.) productivity when grown in sub-optimal conditions including drought, salinity, and cold temperatures. In a field study under irrigation in the Intermountain Western USA, the yield advantage to Kentucky 31 tall fescue infected with wild-type Neotyphodium over endophyte-free Kentucky 31 was greatest (over $15 \%$ ) when irrigation was severely limited to natural precipitation. In an evaluation of salinity tolerance there were no significant differences in plant $\mathrm{LD}_{50}$ values due to endophyte infection. In a recent study Jesup MaxQ recovered better from winter injury than Jesup E- when grown in a high-elevation colddesert, irrigated environment. These studies suggest the need for additional research to elucidate the potential advantages of wildtype and novel endophytes for tall fescue production in irrigated environments typical of the semiarid western USA.
\end{abstract}

Keywords: tall fescue, Festuca arundinacea Schreb.,

Neotyphodium, drought tolerance, salinity tolerance,

winterhardiness

\section{Introduction}

Tall fescue (Festuca arundinacea Schreb.) is the predominant forage grass throughout the humid and subhumid eastern half of the United States, and is especially well adapted to the central transition zone (Moore 2003). In the western region of the USA, tall fescue's range of adaptation is limited by inadequate precipitation; even so, it is one of the most productive pasture grasses when grown with supplemental irrigation (Waldron et al. 2002). Unlike the eastern USA, endophytefree rather than endophyte infected tall fescue is predominant in the western part of the country. However, increased grazing pressure on privately-owned, irrigated pastures, combined with severe water shortages, necessitates maximizing tall fescue's productivity when grown in sub-optimal conditions including drought, salinity, and cold temperatures.

The symbiotic relationship between Neotyphodium infection and tall fescue is well documented, showing increased insect, heat, and drought tolerance resulting in improved persistence and summer survival in the eastern USA (West et al. 1993). Malinowski and Belesky (2000) reviewed the mechanisms of endophyte-induced drought adaptation, including improved drought avoidance through expanded root growth and greater drought tolerance by better water use efficiency. West et al. (1993) reported that endophyte-infected tall fescue had enhanced tiller survival under zero irrigation as opposed to endophyte free stands, yet there was no consistent advantage to forage yield. Hesse et al. (2003) found that Neotyphodium-infected perennial ryegrass (Lolium perenne L.) collections that originated from dry sites in Germany had increased regrowth under drought than their uninfected counterparts. Conversely, it has also been reported that endophyte infection did not increase survival or growth of perennial ryegrass grown under low irrigation (Lewis 1992).

There has been less research to investigate the potential role of endophyte infection on increased grass tolerance to saline conditions and cold temperatures. One study found no benefit in growth between $F$. rubra plants infected or uninfected with Epichloe endophyte when watered with seawater (Zabalgogeazcoa et al. 2006). Likewise, Simpson and Hume (2000) reported no relationship between salt tolerance and endophyte infection for tall fescue and perennial ryegrass. However, it was recently shown that barley (Hordeum vulgare L.) infected with the exotic endophyte Piriformspora indica was more tolerant to moderate salt stress than non-infected barley (Waller et al. 2005).

The relative effect of endophyte infection on tall fescue's winter survival and winter recovery has not been investigated. Likewise, there has been little research to evaluate possible endophyte benefits to adaptation and production of grasses in irrigated pastures of the semiarid, cold-desert environments typical of the western USA. We report here findings from a series of investigations conducted to elucidate the potential benefit of endophyte infection in tall fescue when grown in the western USA.

\section{Materials and methods}

\section{Drought tolerance}

Asay et al. (2001) evaluated the response of tall fescue to an irrigation gradient in the Intermountain West of the USA. Included in the study was a comparison of wild-type endophyte infected and endophyte free 'Kentucky 31 '. Immunoblot tests confirmed the appropriate endophyte infection in the two entries. Complete results and details of methods can be reviewed in Asay et al. (2001). Here we review only the results at the lowest irrigation level. Briefly, yearly dry matter production (from five clippings) was compared for endophyte-status when tall fescue was grown without supplemental irrigation. The study was conducted in 1997 and 1998 near Logan, Utah, USA. Average precipitation that these plots received during the growing season was $361 \mathrm{~mm}$.

\section{Salt tolerance}

Relative salt tolerance of tall fescue was evaluated in a greenhouse test in 2004. Entries included wild-type endophyte infected and endophyte free Kentucky 31, and novel-type endophyte infected (MaxQ) and endophyte free Jesup. Endophyte infection was confirmed in the Jesup lines, but not verified in the Kentucky 31 lines. The experiment was conducted by slightly modifying the procedures found in Peel et al. (2004). Briefly, the lethal dose to kill $50 \%$ of 20 plants per replicate for each cultivar $\left(\mathrm{LD}_{50}\right)$ was estimated using a replicated design and two separate runs. Sixweek old plants, grown in silica sand, were dipped in a saline solution twice each week. Salt concentration started at an EC of $6 \mathrm{dS} / \mathrm{m}$ and increased in $6 \mathrm{dS} / \mathrm{m}$ increments every 1 week until an EC level of $42 \mathrm{dS} / \mathrm{m}$ was reached, where it remained for an additional 4 weeks of treatment. To account for both relative time and salt concentration, a cumulative linear value was calculated 
that accounted for salt concentration as measured by EC of the solution and the number of days at each EC concentration $\left(\mathrm{EC}_{\text {days }}\right)$. Probit analysis was used to estimate $\mathrm{LD}_{50}$ in terms of $\mathrm{EC}_{\text {days }}$ for each entry on individual replicates, and the results were subjected to mixed model analysis.

\section{Winter hardiness and recovery}

A space-planted trial of tall fescue was established in 2004 near Panguitch, Utah, USA. The area is a high elevation valley (1976 m above sea level) known for cold, open winters and late spring frosts. Kentucky $31 \mathrm{E}+$ and $\mathrm{E}-$, , and Jesup MaxQ and $\mathrm{E}$ - were again included in the test; however, immunoblot test of the material showed that $0 \%$ of the Kentucky $31 \mathrm{E}+$ plants were infected with the endophyte. Infection of Jesup MaxQ and Jesup E- was $100 \%$ and $0 \%$, respectively. The experimental design was a randomised complete block with eight replicates of five-plant plots. Individual plants were visually evaluated for winter injury $(1-9,1=$ winter killed and $9=$ no winter injury) in early May 2005 and 2006. Plots were then harvested three times each year with a sickle-bar harvester to 8-cm stubble at the boot stage of plant development for the first harvest and when the height of regrowth was approximately $40 \mathrm{~cm}$ for subsequent harvests. Forage samples were taken from each plot and dried to a constant weight in a forced-air oven at $70^{\circ} \mathrm{C}$ to determine dry matter percentage. Forage yields were reported as yearly dry matter in $\mathrm{kg} / \mathrm{plot}$ and were representative of tall fescue's ability to recover from winter injury. Analysis revealed a significant Entry $\times$ Year interaction, most likely due to 2004-05 winter being a mild with very little winter injury; therefore, only results from 2005-06 winter are reported.

\section{Results and Discussion}

\section{Drought tolerance}

Dry matter yield of Kentucky $31 \mathrm{E}+$ was significantly $(\mathrm{P}<0.05)$ higher (15\%) than Kentucky $31 \mathrm{E}$ - at the lowest irrigation level of $361 \mathrm{~mm}$ (natural precipitation only) (Table 1). Asay et al. (2001) reported that this difference was even more pronounced when yield was based only on late-season harvests after an obvious irrigation gradient existed due to loss/use of soil water reserves. West et al. (1993) could not associate a forage yield benefit to endophyte infection when tall fescue was grown under limited irrigation. However, their lowest irrigation (precipitation only) of approximately $540 \mathrm{~mm}$ is more comparable to the midirrigation levels reported in Asay et al. (2001) for which, in similar fashion, a trend for higher yield, although not significant, was found in favour of endophyte infection. Burns and Chamblee (1979) report that tall fescue is adapted to dryland conditions in the western USA when annual precipitation is approximately
$500 \mathrm{~mm}$; whereas, it lacks sufficient drought tolerance to persist when annual precipitation approaches $300 \mathrm{~mm}$. It may be that endophyte enhancement of drought tolerance supercedes the plants own genetic expression somewhere between this 500 to $300 \mathrm{~mm}$ range. Based on these results, we would conclude that Neotyphodium may increase forage production of tall fescue when irrigation is limited in the western USA. However, additional studies are needed to further document the potential effect of wild-type and novel-type endophytes on persistence and forage yield of tall fescue grown under limited irrigation in the semiarid, cold-desert region of the USA.

\section{Salt tolerance}

We found no significant differences in $\mathrm{LD}_{50}$ values between Kentucky $31 \mathrm{E}+$ and E- lines, or between Jesup MaxQ and Jesup E- lines (Table 1). These results support Simpson and Hume (2000) findings that Neotyphodium confers little if any increased salt tolerance to tall fescue. However, in our overall study, we found very little genetic variation among tall fescue lines for salt tolerance as determined by plant death (data not shown). Because of this and absolute differences in favour of endophyte infected over endophyte free material, we feel additional research is warranted. To this end we are now investigating forage growth reduction (as opposed to death) at more moderate salinity levels.

\section{Winter hardiness and recovery}

There was no significant difference between Jesup MaxQ versus Jesup E- for winter injury (Table 1). Jesup is not adapted to the cold winter and spring temperatures typical of this environment, finishing near the bottom of the test. This suggests the possibility, that in this case, plant genetics made any endophyte enhancement ineffective. However, we did observe that approximately 20$30 \%$ of individual plants of Jesup MaxQ had little winter injury; whereas the remaining $70-80 \%$ of plants within the same plots were severely injured. We did not see this type of variable injury among plants of the other entries. The Jesup MaxQ plants with little winter injury contributed to, but were not solely responsible, for a significantly higher subsequent forage yield over the Jesup E- line (Table 1). We surmised that the uninjured Jesup MaxQ plants may have had a high level of endophyte expression, but this was not verified and our previous test had shown $100 \%$ infection in MaxQ plants. Overall, we concluded that Jesup MaxQ was better able to recover from winter injury as compared to Jesup E-. These results suggest that the novel endophyte may have a role in increasing recovery from winter injury. Additional research using adapted plant material is needed.

In conclusion, these studies suggest endophyte infection may improve abiotic stress tolerance in tall fescue grown in the

Table 1 Summary of performance data comparing endophyte status of tall fescue when evaluated under abiotic stress in Utah (USA).

\begin{tabular}{lcccc}
\hline Entry & $\begin{array}{c}\text { Drought } \\
\text { Yield (Mg/ha) }\end{array}$ & $\begin{array}{c}\text { Salt } \\
\text { LD }_{50}(\mathrm{EC} \text { days })\end{array}$ & $\begin{array}{c}\text { Winter hardiness } \\
\text { Visual Injury 1-9 } \\
\text { (1=dead) }\end{array}$ & $\begin{array}{c}\text { Winter recovery } \\
\text { Yield (kg/ plot) }\end{array}$ \\
\hline Kentucky 31 E+ & 17.6 & 2746 & --- & --- \\
Kentucky 31 E- & 14.9 & 2672 & --- & --- \\
Jesup MaxQ & --- & 2653 & 2.2 & 3.4 \\
Jesup E- & --- & 2622 & 2.2 & 2.8 \\
LSD (0.05) & 1.9 & 158 & 0.7 & 0.4 \\
\hline
\end{tabular}


irrigated pastures of the western USA. However, the studies were not conclusive and additional research is needed. Using adapted plant materials infected with both wild-type and novel endophytes will help elucidate the future role of endophytes in this area. Potential benefits will need to be carefully documented and shown to compensate for cattle performance issues of wild-type Neotyphodium and higher seed prices of novel-type endophyte/seed packages.

\section{REFERENCES}

Asay, K.H.; Jensen, K.B.; Waldron, B.L. 2001. Responses of tall fescue cultivars to an irrigation gradient. Crop Science 41: 350-357.

Burns, J.C.; Chamblee, D.S. 1979. Chapter 2: Adaptation. pp. 9-30. In: Tall Fescue. 1st ed. Agronomy. Monograph. 20. Eds. Buckner, R.C.; Bush, L.P. ASA-CSSA-SSSA, Madison, Wisconsin.

Hesse, U.; Schöberlein, W.; Wittenmayer, L.; Förster, K.; Warnstorff, K.; Diepenbrock, W.; Merbach, W. 2003. Effects of Neotyphodium endophytes on growth, reproduction and drought-stress tolerance of three Lolium perenne L. genotypes. Grass and Forage Science 58: 407-415.

Lewis, G.C. 1992. Effect of ryegrass endophyte in mixed swards of perennial ryegrass and white clover under two levels of irrigation and pesticide treatment. Grass and Forage Science 47: 302-305.

Malinowski, D.P.; Belesky, D.P. 2000. Adaptations of endophyteinfected cool-season grasses to environmental stresses: Mechanisms of drought and mineral stress tolerance. Crop Science 40: 923-940.
Moore, K.J. 2003. Compendium of common forages. pp. following 236. In: Forages: An Introduction to Grassland Agriculture. Volume 1. 6th ed. Eds. Barnes, R.F.; Nelson, C.J.; Collins, M.; Moore, K.J. Iowa State Press, Ames, Iowa.

Peel, M.D.; Waldron, B.L.; Jensen, K.B.; Chatterton, N.J.; Horton, H.; Dudley, L.M. 2004. Screening for salinity tolerance in alfalfa: a repeatable method. Crop Science 44: 2049-2053.

Simpson, W.R.; Hume, D.E. 2000. An examination of the potential mitigation effect of Neotyphodium infection on grasses exposed to elevated salt concentration. pp. 381-385. In: Proceedings of the 4th International Neotyphodium/Grass Interactions Symposium.

Waldron, B.L.; Asay, K.H.; Jensen, K.B. 2002. Stability and yield of cool-season pasture grass species grown at five irrigation levels. Crop Science 42: 890-896.

Waller, F.; Achatz, B.; Baltruschat, H.; Fodor, J.; Becker, K.; Fischer, M.; Heier, T.; Hückelhoven, R.; Neumann, C.; von Wettstein, D.; Franken, P.; Kogel, K.-H. 2005. The endophytic fungus Piriformospora indica reprograms barley to salt-stress tolerance, disease resistance, and higher yield. Proceedings of the National Academy of Science 102: 13386-13391.

West, C.P.; Izekor, E.; Turner, K.E.; Elmi, A.A. 1993. Endophyte effects on growth and persistence of tall fescue along a watersupply gradient. Agronomy Journal 85: 264-270.

Zabalgogeazcoa, I.; Romo, M.; Keck, E.; Vázquez de Aldana, B.R.; García Ciudad, A.; García Criado, B. 2006. The infection of Festuca rubra subsp. pruinosa by Epichloëfestucae. Grass and Forage Science 61: 71-76. 